\title{
MANIFESTATIONS OF MODIFICATION CAPACITY OF WINTER TRITICALE GENOTYPES OF FOREST-STEPPE AND POLISSYA ECOTYPES
}

Moskalets V., Moskalets T.

Bila Tserkva National Agrarian University, Ukraine

We experimentally studied biocenotic manifestations of modification capacity of winter triticale genotypes of Forest-Steppe and Polissya ecotypes depending on agro-ecological factors. Winter triticale cultivars were studied as ecomorphological geocenoconsortiums that defined agroecological assessment of them, depending on genotypic and phenotypic characteristics.

The aim and tasks of the study. The study purpose - to substantiate theoretically and develop methodological bases of ecosystem formation of highly productive winter triticale phytocenoses in the Forest-Steppe and Polissya of Ukraine.

Material and Methods. The stationary studies were carried out in the Forest-Steppe, ForestSteppe/Pollisya transition zone, and Pollisya. Winter triticale phytocenosis status was evaluated by morphological, biological and valuable economic traits of agrophytocenoses, their suitability for use in certain conditions of an ecotope. Parameters of yield structure elements, course of phenological developmental phases, dynamics of plant growth increment, length of growing season, leaf area, net photosynthetic productivity, photosynthetic potential, root system parameters in different soil horizons and tops were determined. Winter hardiness of ecomorphs in experiments was evaluated according to data of autumn and spring surveys od phytocenosis status.

Results and Discussion. A scheme to create sustainable highly productive winter triticale phytocenoses at various hierarchical levels (autecological, demecological, consortium, zonal, biocenotic, ecosystem) through breeding and testing of ecomorphs (hybrids, lines) having a number of valuable economic and environmental traits was suggested. In addition to morphological and physiological characteristics of cultivars of specific ecotypes, ecomorphic peculiarities of cultivar response to impact of certain agrotechnical factors (mineral fertilizers, microbial agents, predecessors, seeding rate and timing) were proposed to use.

Conclusions. Identification of winter triticale cultivars as ecomorphs provided design of a logically order

Key words: winter triticale ecomorphs, ecotope conditions, technology of cultivation, yield capacity, grain quality, autecological, demecological and synecological levels

УДК: 635.21:631.532.4

\section{ПЕРСПЕКТИВНІСТЬ ДЛЯ СЕЛЕКЦЇ̈ РІЗНИХ ЗА СТИГЛІСТЮ МІЖВИДОВИХ ГІБРИДІВ КАРТОПЛІ ЗА ВМІСТОМ КРОХМАЛЮ І ЙОГО ВИХОДОМ}

Подгаєцький А. А., Крючко Л. В.

Сумський національний аграрний університет, Україна

У статті викладено результати дослідження щодо селекційної цінності різних за стиглістю міжвидових гібридів картоплі, створених за участю мексиканських диких видів, за вмістом крохмалю у бульбах та виходом його в перерахунку на рослину. Доведено, що потенціал преважної кількості беккросів за проявом ознак є значно вищим, ніж у сортівстандартів. Встановлено значний вплив метеорологічних умов років виконання дослідження на прояв ознак.

(C) А. А. Подгаєцький, Л. В. Крючко. 2015.

ISSN 0582-5075. Селекція і насінництво. 2015. Випуск 107. 
Ключові слова: картопля, міжвидовий гібрид, беккрос, уміст крохмалю, вихід крохмалю, метеорологічні умови

Вступ. Картопля - одна 3 найпоширеніших сільськогосподарських культур у світі. За площами садіння вона займає п'яте місце після пшениці, рису, кукурудзи і сорго, а за валовими зборами - четверте, переважаючи сорго [1]. Цінність ії не лише у великій популярності серед населення, але, разом з бататом, у найбільшому виробництві енергії з одного гектара та продукуванні максимальної, порівняно з іншими культурами, кількості білка $(1,1$ кг/га) [2]. Це в 1,4 рази більше, ніж у кукурудзи і 1,8 рази - ніж у рису і квасолі. Крім цього, білок бульб картоплі характеризується наявністю багатьох незамінних амінокислот [3]. Високу харчову цінність має також крохмаль бульб картоплі. Він засвоюється в організмі людини за 10 хвилин, тоді як, наприклад, кукурудзи, пшениці і рису - впродовж двох годин [4]. Водночас, доведений різний прояв агрономічних ознак сортів, гібридів картоплі залежно від групи стиглості зразків.

Аналіз літературних даних, постановка проблеми. Починаючи з середини минулого сторіччя, міжвидова гібридизація картоплі стає основним методом селекції. Завдяки ії застосуванню вдалося вирішити численні проблеми, які ставили під сумнів можливість вирощування культури [5]. Наприклад, близькість у генетичному відношенні сортів картоплі, які вирощувалися в Ірландії в середині 60-х років позаминулого сторіччя, поява нових рас фітофтори зумовили значні епіфітотії хвороби в 1845, 1846 і 1848 роках, що спричинило зменшення населення країни на третину [6]. Ще однією позитивною стороною інтрогресії цінних генів контролю багатьох ознак, які відсутні у культурних сортів, виявилося розширення генетичної основи міжвидових гібридів, що в свою чергу дозволило виділяти гетерозисні форми за багатьма полігенними ознаками [7]. Водночас, в процесі міжвидової гібридизації поряд з ефективним генетичним контролем агрономічних ознак передаються потомству і негативні ознаки. Зокрема, часто це стосується пізньостиглості, яка сама по собі не є небажаною ознакою, бо в численних рекомендаціях відмічається необхідність вирощувати у виробництві різні за стиглістю сорти. Використовуючи найрізноманітніші методи 3 подолання міжвидової несумісності [8], в Інституті картоплярства вдалося залучити до створення вихідного передселекційного та селекційного матеріалу цінний у багатьох відношеннях дикий мексиканський вид картоплі S. bulbocastanum Dun. [9]. Одержані гібриди досліджено за багатьма агрономічними ознаками $[10,11,12]$, проте не було оцінено матеріал за терміном дозрівання, хоча окремі дослідження дозволили стверджувати про можливість отримання при використанні цього матеріалу різних за групами стиглості гібридів, у тому числі і скоростиглих [13].

Метою дослідження було виявити потенціал різних за стиглістю міжвидових гібридів, їх беккросів за вмістом крохмалю, його виходом у перерахунку на рослину та вплив на прояв ознак метеорологічних умов у роки виконання експерименту.

Матеріали і методи. Методика дослідження загальноприйнята в картоплярстві [14], зокрема оцінка вихідного передселекційного та вихідного селекційного матеріалу. Вихідним матеріалом були міжвидові гібриди, одержані за участю трьох-, чотирьох-, п’яти- і шести диких і культурних видів. Загальне для всіх них - присутність у родоводі виду S. bulbocastanum. Вони створювалися методами беккросування, самозапилення на різних етапах і схрещування гібридів між собою.

Обговорення результатів. Тривалість періоду вегетації сортів, гібридів картоплі складна за генетичним контролем ознака. Крім цього, на іï прояв значною мірою впливають зовнішні чинники, перш за все метеорологічні. Причому вплив на процеси утворення цукрів під час фотосинтезу, транспортування цих речовин у бульби, перетворення моносахаридів у полісахариди тощо $є$ різним.

Отримані дані (табл. 1) свідчать про неоднакову кількість оціненого матеріалу за групами стиглості. Це пов'язано з численними причинами: різним проявом стиглості міжвидових гібридів, їх беккросів за роками, відсутністю можливості визначення вмісту крохмалю у всього матеріалу тощо. 
Розподіл міжвидових гібридів, їх беккросів різних груп стиглості за вмістом крохмалю у бульбах, \%

\begin{tabular}{|c|c|c|c|c|c|c|c|c|c|}
\hline \multirow[b]{2}{*}{ Стиглість } & \multirow{2}{*}{$\begin{array}{c}\text { Оцінено, } \\
\text { шт. }\end{array}$} & \multicolumn{8}{|c|}{ Частка гібридів з умістом крохмалю, \% } \\
\hline & & $\begin{array}{c}10,0 \\
\mathrm{i}<\end{array}$ & $\begin{array}{c}10,1- \\
12,0\end{array}$ & $\begin{array}{r}12,1- \\
14,0\end{array}$ & $\begin{array}{r}14,1- \\
16,0\end{array}$ & $\begin{array}{c}16,1- \\
18,0\end{array}$ & $\begin{array}{c}18,1- \\
20,0\end{array}$ & $\begin{array}{c}20,1- \\
22,0\end{array}$ & $\begin{array}{r}> \\
2,0\end{array}$ \\
\hline \multicolumn{10}{|c|}{$2012 \mathrm{p}}$. \\
\hline Ранньостиглі & 9 & 88,9 & 11,1 & - & - & - & - & - & - \\
\hline Середньоранні & 56 & 62,5 & 25,0 & 8,9 & 1,8 & - & 1,8 & - & - \\
\hline Середньостиглі & 93 & 50,5 & 23,7 & 21,5 & 4,3 & - & - & - & - \\
\hline Середньопізні & 63 & 53,9 & 17,5 & 19,1 & 6,3 & - & 1,6 & - & 1,6 \\
\hline Пізньостиглі & 20 & 25,0 & 35,0 & 20,0 & 15,0 & 5,0 & - & - & - \\
\hline Дуже пізньостиглі & 9 & 44,5 & 22,2 & 22,2 & 11,1 & - & - & - & - \\
\hline \multicolumn{10}{|c|}{$2013 \mathrm{p}$} \\
\hline Ранньостиглі & 5 & 60,0 & - & - & 20,0 & 20,0 & - & - & - \\
\hline Середньоранні & 25 & 36,0 & 20,0 & 16,0 & 12,0 & 4,0 & 8,0 & 4,0 & - \\
\hline Середньостиглі & 76 & 47,4 & 15,8 & 10,5 & 10,5 & 6,6 & 6,6 & 1,3 & 1,3 \\
\hline Середньопізні & 58 & 36,2 & 13,8 & 17,2 & 13,8 & 10,3 & 5,2 & 3,5 & - \\
\hline Пізньостиглі & 20 & 10,0 & 15,0 & 15,0 & 30,0 & 5,0 & - & 5,0 & 5,0 \\
\hline Дуже пізньостиглі & 5 & - & - & 20,0 & 20,0 & - & 40,0 & - & 20,0 \\
\hline \multicolumn{10}{|c|}{$2014 \mathrm{p}}$. \\
\hline Ранньостиглі & 5 & 40,0 & - & 40,0 & - & 20,0 & - & - & - \\
\hline Середньоранні & 32 & 12,5 & 28,1 & 15,6 & 15,6 & 12,5 & 6,3 & 6,3 & 3,1 \\
\hline Середньостиглі & 49 & 8,2 & 18,4 & 16,3 & 28,6 & 14,3 & 8,2 & 4,1 & 2,0 \\
\hline Середньопізні & 74 & 23,0 & 9,5 & 16,2 & 14,9 & 21,6 & 12,2 & 2,7 & - \\
\hline Пізньостиглі & 27 & 25,9 & 18,5 & 18,5 & 7,4 & 22,2 & 3,7 & - & 3,7 \\
\hline Дуже пізньостиглі & 8 & - & 25,0 & - & 37,5 & - & 12,5 & - & 25,0 \\
\hline
\end{tabular}

Найбільш несприятливими метеорологічними умовами для накопичення крохмалю виявились у 2012 році. Особливо це стосувалося гібридів окремих груп стиглості. Наприклад, усі ранньостиглі форми віднесено лише до перших двох класів. До того ж переважаюча їх кількість характеризувалася дуже низьким проявом ознаки - 10 \% і менше. Сортстандарт Серпанок у цьому році мав уміст крохмалю 9,9 \%. Тобто, в несприятливих зовнішніх умовах серед ранньостиглих гібридів відібрати хоча б із середнім вираженням показника не вдавалося.

Дещо інше, спостерігалося у середньоранніх гібридів. Серед них також максимальна частка матеріалу (62,5 \% від виділених в цій групі стиглості) мала дуже низький вміст крохмалю. У наступному класі частка матеріалу становила 25,0%. Сюди ж віднесено і сорт-стандарт Світанок київський з рівнем ознаки 10,5 \%. Водночас у дворазового беккроса шестивидового гібрида 01.37Г120, у якого на етапі опрацювання вторинних міжвидових гібридів одержано самозапилення, вміст крохмалю становив 19 \%, що для цієї групи стиглості є досить високим вираженням показника.

У цілому відмічено тенденцію зниження частки гібридів з дуже низьким умістом крохмалю (перші два класи) із збільшенням періоду вегетації рослин. Наприклад, поміж середньостиглих міжвидових гібридів, їх беккросів, віднесених до класу з проявом ознаки $10 \%$ і менше, частота матеріалу виявилася нижчою порівняно з середньоранніми на $12 \%$ i меншою, ніж у ранньостиглих, на 33,4 \%. Крім цього, значно більше середньостиглих гібридів віднесено до класів з рівнем ознаки 12,1-14,0 \% і 14,1-16,0\%, хоча сорт-стандарт Явір характеризувався вмістом крохмалю на рівні 10,2 \%. Водночас, у останніх чотирьох класах форм з відповідною тривалістю вегетації не виявлено.

Близькі значення розподілу матеріалу за вмістом крохмалю порівняно з середньостиглими гібридами мали середньопізні, хоча в сорту-стандарту Тетерів прояв ознаки ста- 
новив 11,1\%. Особливість вираження ії у гібридів зводилася до більшої їх частки з середнім проявом показника - 14,1-16,0 \%, що, порівняно з матеріалом попередніх груп стиглості, виявилося максимальним. Крім цього, виділено один беккрос 3 крохмалистістю 20 \%. Це 91.285c5 - триразовий беккрос п’ятивидового гібрида та аналогічного за походженням гібрида 90.841с21 з проявом ознаки 24 \%. Материнською формою обох гібридів є дворазовий беккрос п’ятивидового гібрида 87.791c4; виходячи з викладеного він може бути донором високої крохмалистості.

Найменшою часткою низькокрохмалистого матеріалу характеризувались пізньостиглі беккроси, хоча до перших двох класів серед них віднесено 60,0 \% форм. Ще одна особливість гібридів цієї групи стиглості - максимальна частота матеріалу з середнім умістом крохмалю (14,1-16,0 \%), а також наявність одного беккроса 3 підвищеною крохмалистістю (17 \%).

Близьким до розподілу пізньостиглих гібридів характеризувалися дуже пізньостиглі. Незважаючи на те, що до першого класу у них віднесено значно більше матеріалу, ніж у пізньостиглих, проте у наступному його виявилося набагато менше. Тобто за сумою гібридів, віднесених до перших двох класів, дуже пізньостиглі гібриди відрізнялися від пізньостиглих на $6,7 \%$, що $є$ не дуже значною величиною.

Зовсім інший, порівняно з 2012 роком, мав місце розподіл досліджуваного матеріалу різних груп стиглості за вмістом крохмалю у 2013 році. Незважаючи на дуже невелику кількість ранньостиглих гібридів, окремі з них мали середній і підвищений уміст крохмалю, хоча в сорту-стандарту Серпанок прояв ознаки був дуже низьким - 9,0 \%. Цінною $є$ можливість виділення в цій групі стиглості гібрида з підвищеним рівнем самозапилення 17,7 \%. Ним був чотириразовий беккрос, одержаний самозапиленням вторинного шестивидового гібрида П 55/62. Тобто за сприятливих зовнішніх умов серед ранньостиглих гібридів можна виділити зразки з відносно високим фенотиповим проявом ознаки.

Широкий спектр вираження показника в 2013 році відмічено у середньоранніх гібридів. Незважаючи на те, що модальним виявився клас з дуже низьким умістом крохмалю, за винятком останнього класу, у кожному з інших присутні середньоранні гібриди. Сортстандарт Світанок київський також віднесено до третього класу із значенням показника 13,8 \%. Особливо цінним для практичного селекційного використання була наявність гібридів з відносно високою і високою крохмалистістю. Першими з них були дворазовий беккрос, одержаний самозапиленням вторинного міжвидового гібрида П 55/62 - 01.29Г26 3 умістом крохмалю 18,6 \% і аналогічний беккрос лише із заміною на останньому етапі схрещування сорту Поліська рожева на Невська - $01.37 Г 70 з$ умістом крохмалю 19,5 \%. Подібність походження згаданих беккросів свідчить про цінність компонентів схрещування, зокрема гібрида 91.318-6, для отримання не лише відносно ранньостиглого потомства, але й з високою крохмалистістю. Ще вищим проявом ознаки характеризувався середньоранній дворазовий беккрос тривидового гібрида 91.765/27 з крохмалистістю 20,8 \%.

Середньостиглі гібриди мали представництво в усіх класах, включаючи клас з дуже високим умістом крохмалю - більше 22,0 \%. Водночас слід відмітити значну частку гібридів цієї групи стиглості у першому (47,4 \%) і наступному $(15,8$ \%) класах, хоча сортстандарт Явір віднесено до третього класу. Також одноразовий беккрос шестивидового гібрида 90.676/67 мав уміст крохмалю у бульбах 20,1 \%, а одноразовий беккрос, одержаний за участю дещо іншого шестивидового гібрида 81.385 с97 характеризувався дуже високою крохмалистістю - 27,4\%.

Незважаючи на відсутність гібридів у останньому класі, середньопізні беккроси проявили значний потенціал за рівнем ознаки. Це ж стосувалося сорту-стандарту Тетерів з умістом крохмалю 21,5 \%. Крім цього, сума часток матеріалу, віднесеного до перших двох класів, у них менша порівняно з середньостиглими гібридами на 13,2 \%, а два гібриди цієї групи стиглості мали високий уміст крохмалю. Це дворазовий беккрос шестивидового гібрида $01.50 Г 6$ з проявом ознаки 21,1 \% і чотириразовий беккрос від схрещування з потомком від самозапилення шестивидового гібрида П 55/62 - 01.52Г39 з рівнем показника $21,5 \%$.

Необхідно відзначити, що материнською формою у беккроса $01.50 Г 6$ був гібрид 90.676/210 з популяції, яка обумовила вищеплення іншого гібрида - 90.676/67, що в свою чергу характеризувався високим умістом крохмалю - 20,1\%. 
У цілому порівняно висока крохмалистість властива пізньостиглим гібридам. Частка їх з дуже низьким і низьким вираженням показника становила лише 25,0 \% і виявилася найменшою серед усіх згаданих раніше груп стиглості. Найвищою у 2013 році також була частка пізньостиглих гібридів (30,0 \%) з середнім проявом ознаки - 14,1-16,0 \%. Цінною для практичного використання виявилася можливість виділення гібридів з високою і дуже високою крохмалистістю. До першого класу із згаданих віднесено дворазовий беккрос шестивидового гібрида $88.730 \mathrm{c} 3$, що мав значенням показника 21,0 \%, а до останнього - шестивидовий гібрид $83.433 \mathrm{c} 6$ з рівнем ознаки 23,3\%.

Підтвердженням високого потенціалу гібридів з тривалим періодом вегетації за вмістом крохмалю у бульбах може бути відсутність дуже пізньостиглих форм у перших двох класах. Крім цього, два беккроси із згаданої групи стиглості характеризувалися відносно високою крохмалистістю - 18,1-20,0 \%, а один віднесено до останнього класу. Це чотириразовий беккрос, отриманий самозапиленням шестивидового гібрида П 55/62, у якого рівень ознаки сягав $23,4 \%$.

Найбільш сприятливі метеорологічні умови для накопичення крохмалю у бульбах виявилися в 2014 році. Але це стосувалося гібридів не всіх груп стиглості. Наприклад, розподіл за рівнемпоказника у ранньостиглих форм не набагато відрізнявся від даних 2013 року. Однаково велику частку матеріалу із згаданою характеристикою віднесено в 2014 році до дуже низькокрохмалистих $(10,0 \%$ і менше) та 3 порівняно низьким рівнем ознаки (12,1-14,0 \%). Низькою крохмалистістю характеризувався також сорт-стандарт Серпанок. Як і в попередньому році, лише один беккрос мав підвищену крохмалистість.

Модальним класом розподілу середньоранніх гібридів виявився клас з низьким рівнем показника. Частка матеріалу у ньому становила 28,1 \%. Водночас матеріал цієї групи стиглості хоча і з меншою частотою, але був присутнім в усіх класах. Цінною виявилася можливість виділення середньоранніх гібридів з високим фенотиповим проявом ознаки. У класі з крохмалистістю 18,1-20,0 \% їх частка становила 6,3% (два беккроси). Відносно високим проявом ознаки характеризувався в цьому році сорт-стандарт Світанок київський - 19,2 \%. До наступного класу з високим рівнем ознаки 20,1-22,0 \% віднесено чотириразовий беккрос від самозапилення вторинного міжвидового гібрида П 55/62 - 01.26Г105 3 умістом крохмалю 21,5 \% і потомок від схрещування на передостанньому етапі двох міжвидових гібридів - 04.108/49 з проявом ознаки 20,8 \%. До останнього класу віднесено дворазовий беккрос тривидового гібрида 09.17/1, у якого вміст крохмалю у бульбах становив 29,1 \%, що класифікується як дуже високий рівень.

Хоча середньостиглі гібриди і мали представництво в кожному з класів розподілу матеріалу, проте його характер був інший, ніж у середньоранніх. Модальним класом з часткою гібридів 28,6 \% був клас із середнім рівнем ознаки. Кількість матеріалу з відносно високою крохмалистістю була в два рази більшою порівняно з середньоранніми гібридами, хоча до останніх двох класів викладене не відносилося. До класу з проявом ознаки в межах 20,1-22,0 \% віднесено триразовий беккрос шестивидового гібрида 96.977/3 з умістом крохмалю 20,3 \% і сіянець 118 комбінації 01.26, який мав рівень ознаки 21,7 \%. Дуже високим умістом крохмалю характеризувався триразовий беккрос п’ятивидового гібрида 90.841с21, у якого прояв ознаки сягав $24,2 \%$, що для його групи стиглості є значною величиною. У сприятливому для накопичення крохмалю 2014 році його вміст у середньостиглого сортустандарту Явір становив 17,0 \%, що перевищує значення модального класу.

Отримані дані дозволяють стверджувати, що умови 2014 р. були порівняно несприятливими для накопичення крохмалю у середньопізніх і пізньостиглих гібридів. При порівнянні з попереднім роком частка матеріалу, віднесена до першого класу середньопізніх гібридів, була меншою на 13,2 \%, але у пізньостиглих вона була більшою на 15,9 \%. Крім цього, в 2014 році в середньопізніх гібридів був відсутнім матеріал з дуже високим рівнем показника, а в пізньостиглих - 3 високим. Рівень ознаки в середньопізнього стандарту - сорту Тетерів становив у цьому році 16,2 \%, що характеризувалося як підвищена крохмалистість.

Модальним класом розподілу гібридів за вмістом крохмалю у середньопізніх гібридів був клас 3 мінімальним його рівнем, хоча і не 3 дуже великою часткою $-23,0$ \%. Близьке значення показника виявлено в класі $з$ підвищеною крохмалистістю - 16,1-18,0 \%. Порі- 
вняно велика кількість гібридів цієї групи стиглості - дев'ять штук - характеризувалася відносно високим вираженням ознаки, а ще два гібриди мали високу крохмалистість. Це одноразовий беккрос шестивидового гібрида 96.965/45 з умістом крохмалю 21,8 \% та дворазовий беккрос шестивидового гібрида, у якого на попередніх етапах відбулося схрещування міжвидових гібридів - 01.40Г4 з рівнем ознаки 21,3\%.

Серед пізньостиглих беккросів в умовах 2014 року лише один віднесено до класу 3 відносно високим рівнем показника, а 90.666/13, потомок від самозапилення одноразового беккроса шестивидового гібрида, характеризувався дуже високою крохмалистістю - 26,0 \% .

Зважаючи на порівняно невелику кількість дуже пізньостиглих форм, розподіл їх за класами нерівномірний: з восьми класів гібриди присутні лише в половини. Особливість матеріалу цієї групи стиглості в модальному класі з середнім умістом крохмалю. Лише один гібрид характеризувався відносно високою крохмалистістю - в межах 18,1-20,0 \%, а ще два мали дуже високий рівень ознаки. До останніх відносилися дворазовий беккрос чотиривидового гібрида 88.790с10 з умістом крохмалю 24,2 \%, у якого на перших етапах застосовано метод самозапилення та одноразовий беккрос семивидового гібрида за участю, крім використаних у дослідженні видів, S. megistacrolobum Bitt. Уміст крохмалю у нього становив $28,1 \%$.

Підсумовуючим показником, який об'єднує вміст крохмалю у бульбах і продуктивність $є$ вихід крохмалю у перерахунку на рослину. Прояв цієї ознаки залежить від генотипу. Але в будь-якому випадку важливим $\epsilon$ вихід крохмалю у перерахунку на рослину бо саме він розкриває взаємозв'язокміж сухою речовиною і вологою в урожаї.

На рівень підсумовуючого показника значно впливають метеорологічні умови років виконання дослідження (табл. 2).

Таблиця 2

Розподіл міжвидових гібридів, їх беккросів різних груп стиглості за виходом крохмалю, \%

\begin{tabular}{|c|c|c|c|c|c|c|c|}
\hline \multirow[b]{2}{*}{ Стиглість } & \multirow[b]{2}{*}{$\begin{array}{c}\text { Оцінено, } \\
\text { шт. }\end{array}$} & \multicolumn{6}{|c|}{ Частка гібридів з виходом крохмалю, г } \\
\hline & & $\begin{array}{r}40,0 \text { i } \\
\text { менше }\end{array}$ & $\begin{array}{c}40,1- \\
80,0\end{array}$ & $\begin{array}{l}80,1- \\
120,0\end{array}$ & $\begin{array}{c}121,1- \\
160,0\end{array}$ & $\begin{array}{c}161,1- \\
200,0\end{array}$ & $\begin{array}{c}\text { більше } \\
200,0 \\
\end{array}$ \\
\hline \multicolumn{8}{|c|}{$2012 \mathrm{p}$} \\
\hline Ранньостиглі & 9 & 100,0 & - & - & - & - & - \\
\hline Середньоранні & 56 & 85,7 & 12,5 & - & 1,8 & - & - \\
\hline Середньостиглі & 93 & 80,6 & 15,0 & 1,1 & 2,2 & 1,1 & - \\
\hline Середньопізні & 63 & 84,1 & 12,7 & - & - & 3,2 & - \\
\hline Пізньостиглі & 20 & 80,0 & 15,0 & 5,0 & - & - & - \\
\hline Дуже пізньостиглі & 9 & 88,9 & 11,1 & - & - & - & - \\
\hline \multicolumn{8}{|c|}{$2013 \mathrm{p}$} \\
\hline Ранньостиглі & 5 & 80,0 & 20,0 & - & - & - & - \\
\hline Середньоранні & 25 & 80,0 & 15,0 & 5,0 & - & 5,0 & - \\
\hline Середньостиглі & 76 & 79,0 & 18,4 & 2,6 & - & - & - \\
\hline Середньопізні & 58 & 77,6 & 20,7 & 1,7 & - & - & - \\
\hline Пізньостиглі & 20 & 55,0 & 45,0 & - & - & - & - \\
\hline Дуже пізньостиглі & 5 & 60,0 & 40,0 & - & - & - & - \\
\hline \multicolumn{8}{|c|}{$2014 \mathrm{p}$} \\
\hline Ранньостиглі & 5 & 40,0 & 40,0 & 20,0 & - & - & - \\
\hline Середньоранні & 32 & 40,6 & 28,1 & 18,8 & 12,5 & - & - \\
\hline Середньостиглі & 49 & 16,3 & 57,1 & 10,2 & 8,2 & 4,1 & 4,1 \\
\hline Середньопізні & 74 & 43,2 & 29,7 & 21,6 & - & 1,4 & 4,1 \\
\hline Пізньостиглі & 27 & 44,5 & 25,9 & 25,9 & 3,7 & - & - \\
\hline Дуже пізньостиглі & 8 & 12,5 & 37,5 & 25,0 & 12,5 & - & 12,5 \\
\hline
\end{tabular}


У 2012 році всі ранньостиглі гібриди характеризувалися низьким виходом крохмалю. Це обумовлено як дуже низькою або низькою їх крохмалистістю, так і порівняно невисокою продуктивністю. Аналогічні дані одержано у сорту-стандарту Серпанок із рівнем показника 24,7 г/рослину.

Інше спостерігалося у середньоранніх беккросів, один з яких віднесено до класу 3 виходом крохмалю в межах 121,1-160,0 г/рослину. Невелика частина гібридів цієї групи стиглості - сім штук - характеризувалася рівнем показника вищим за мінімальний.

У середньоранніх гібридів вихід крохмалю значною мірою залежав від його вмісту (див. табл. 1, 2), бо саме високий рівень останнього показника в беккроса 01.37Г120 та деяких інших обумовив порівняно високий його вихід. У сорту-стандарту Світанок київський вихід крохмалю становив 32,5 г/рослину, що можна характеризувати як низький.

Протилежне до викладеного вище спостерігалося у середньостиглих гібридів. Крім перших двох класів у них виділено поодинокі беккроси ще в трьох. Наявність їх дозволяє характеризувати матеріал цієї групи стиглості як перспективний за виходом крохмалю, що більшою мірою обумовлено їх продуктивністю, а не крохмалистістю. Аналогічне стосувалося сорту-стандарту Явір з проявом ознаки 36,2 г/рослину.

Порівняно несприятливими зовнішніми умовами періоду вегетації картоплі в 2012 році спричинено належність більшості середньопізніх гібридів у перших двох класах розподілу за виходом крохмалю у перерахунку на рослину. Водночас два беккроси (91.318-2 і 90.841с21) мали рівень ознаки 185,3 г та 164,5 г відповідно. У першого з них це обумовлено дуже високою продуктивністю - 1425 г/рослину, а в останнього - дуже високим умістом крохмалю (24 \%) і порівняно високою продуктивністю (700 г/рослину). У беккроса 91.285c5, який характеризувався відносно високим умістом крохмалю, продуктивність у 2012 році виявилася дуже низькою - 150 г/рослину, що спричинило низький вихід крохмалю - 29,9 г. У сорту-стандарту Тетерів у цьому році також виявився низький вихід крохмалю - 35,5 г/рослину.

Розподіл пізньостиглих гібридів за виходом крохмалю у 2012 році відбувався за трьома класами. Особливістю матеріалу, порівняно з іншими групами стиглості, $\epsilon$ найменша частка беккросів у першому класі, хоча вона і складала 80,0 \%. Максимальним рівнем ознаки характеризувався дворазовий беккрос п’ятивидового гібрида 87.791с4 - 84,3 г крохмалю на рослину.

Несприятливими виявилися умови періоду вегетації картоплі в 2012 році для виходу крохмалю у дуже пізньостиглих гібридів. Більшість 3 них віднесено до першого класу 3 максимальним проявом показника 40,0 г/ рослину.

Аналогічним 2012 року, за рідкісним винятком, був рівень виходу крохмалю у перерахунку на рослину у наступному році. Кращі умови для утворення крохмалю спричинили розподіл ранньостиглих форм у двох класах, хоча у кількісному відношенні клас 3 рівнем ознаки в межах 40,1-80,0 г крохмалю на рослину представлено одним гібридом. Водночас, порівняно з 2012 роком, коли всі ранньостиглі беккроси мали вихід крохмалю не більше за 40 г/рослину, умови 2013 року можна вважати більш сприятливими для прояву показника. Протилежне спостерігалося у сорту-стандарту Серпанок, у якого рівень ознаки був дуже низьким (9,0 г/рослину) за низької продуктивності (100 г/рослину) і низької крохмалистості $(9,0 \%)$.

Близькі дані отримано в середньоранніх гібридів. Вони були представлені в чотирьох класах. Особливо виділився в цьому відношенні дворазовий беккрос чотиривидового гібрида $90.827 \mathrm{c5}$, у якого на останньому етапі одержання вторинних міжвидових гібридів використано самозапилення. У нього вихід крохмалю від однієї рослини становив 187,9 г. Сорт-стандарт Світанок київський мав вихід крохмалю набагато нижчий - 13,5 г/рослину.

Розподіл за рівнем ознаки між середньостиглими і середньопізніми гібридами був дуже близьким. Для обох груп стиглості характерною є наявність матеріалу тільки в трьох класах. Сорти-стандарти мали значну різницю у прояві показника: Явір - 23,6 г/рослину, Тетерів - 33,1 г/рослину.

Порівняно із згаданими групами стиглості, значно меншу частку матеріалу, який було віднесено до першого класу, відмічено серед пізньостиглих і дуже пізньостиглих гіб- 
ридів. У перших з них вона була найнижчою у цьому році із значенням показника менше 40 г крохмалю на рослину.

Тобто, незважаючи на наявність серед частини гібридів різних груп стиглості високого вмісту крохмалю, вихід його у перерахунку на рослину, за рідкісним винятком, виявився в 2013 році низьким. Причиною $є$ несприятливі для формування продуктивності, а в деяких випадках і крохмалю метеорологічні умови року.

Порівняно з попередніми роками найбільш сприятливими для накопичення крохмалю і формування продуктивності були умови 2014 року Мінімальну кількість класів гібридів відмічено в ранньостиглих форм. Водночас частка матеріалу у першому і другому класах була однаковою, що не спостерігалося у жодному з попередніх років, а один гібрид дворазовий беккрос тривидового гібрида 04.122/145 характеризувався рівнем ознаки 82,3 г. У той же час сорт Серпанок характеризувався низьким виходом - 18,9 г/рослину.

Особливість розподілу середньоранніх гібридів, порівняно з розподілом ранньостиглих, полягає у збільшенні спектру на один клас - 3 виходом крохмалю в межах 121,1160,0 г. До нього віднесено чотири беккроси. Тобто, за сприятливих зовнішніх умов можна виділити середньоранні гібриди з відносно високим виходом крохмалю. Порівняно 3 іншими стандартами, високим виходом крохмалю характеризувався сорт Світанок київський $-59,7$ г/рослину.

Найбільш повне представництво за класами розподілу матеріалу мали в 2014 році середньостиглі гібриди. Ще однією особливістю цієї групи стиглості виявилася кількість гібридів у двох останніх класах - по два. За винятком дуже пізньостиглих бек кросів, у середньостиглих мала місце найменша частка матеріалу у першому класі. Сорт Явір також мав відносно високий вихід крохмалю - 58,5 г/рослину.

Хоча поміж середньопізніх гібридів і вдалося виділити гібриди з дуже високим і високим виходом крохмалю подібно до розподілу середньостиглого матеріалу, проте різниця частки гібридів, віднесених до першого класу, була у перших 3 них на 26,9 \% більшою. Протилежне, хоча і з близьким значенням $(27,4$ \%) спостерігалося у класі виходу крохмалю 40,1-80,0 г/рослину. Сорт-стандарт Тетерів мав рівень ознаки 26,7 г/рослину.

Незважаючи на невелику кількість дуже пізньостиглих гібридів, їх розподіл був відносно рівномірним. Виняток становив клас із значенням показника 161,1-180,0 г/рослину.

Висновки. Виявлено значний потенціал різних за групами стиглості міжвидових гібридів, їх беккросів за вмістом крохмалю. Виняток становили ранньостиглі форми, у яких навіть за сприятливих зовнішніх умов рівень ознаки не перевищував $17 \%$, а модальним класом, крім 2014 року, був клас $з$ дуже низьким рівнем ознаки - 10,0 \% і менше. Поміж середньоранніх виділено гібриди з відносно високою крохмалистістю в умовах 2012 року, несприятливого для його утворення. Ще вищий потенціал у цьому році мали середньопізні гібриди. У відносно сприятливих зовнішніх умовах двох наступних років незалежно від групи стиглості виділено беккроси з високим (20,1-22,0 \%) і дуже високим (більше 22,0 \%) умістом крохмалю. Максимальну частку матеріалу у останньому класі виявлено в дуже пізньостиглих гібридів (20-25\%).

У зв'язку з низькою продуктивністю досліджуваних форм у 2013 році їх розподіл за виходом крохмалю у перерахунку на рослину відрізнявся від розподілу за вмістом крохмалю. Дуже низьким рівнем першої ознаки характеризувалися ранньостиглі гібриди майже в усі роки дослідження. Максимальний вихід крохмалю властивий середньостиглим, середньопізнім і дуже пізньостиглим беккросам. У сприятливому для прояву ознаки 2014 році три середньопізні беккроси - 90.285c9, 01.29Г11 і 04.16с10 - мали вихід крохмалю понад 200 г/рослину.

Перспективи подальших досліджень. Виділені міжвидові гібриди, їх беккроси, які характеризувалися високим фенотиповим проявом окремих або декількох ознак слід широко використовувати в селекційній практиці як батьківські форми. Для більш ефективного застосування доцільно визначити їх комбінаційну здатність за контролем агрономічних ознак. 


\section{Список використаних джерел}

1. FAO Statistical Yeabook, 2014. Europe and Central Asia Food and Agriculture. Food and Agriculture Organization of the Unitid Nations. Regional Offise for Europe and Centrel Asia [Text]. - Budapest, 2014. - $130 \mathrm{p}$.

2. Van der Zaag, D. E. Potato production and utilization in the world [Text] / D. E. Van der Zaag // Pot. Res. - 1976. - № 19. - P. 7-22.

3. Власенко, М. Ю. Морфологія, фізіологія та біохімія картоплі. Т 1. Картопля [Текст] / М. Ю. Власенко. - К., 2002. - С. 54 - 115.

4. Гогулян, М. Проститесь с болезнями [Текст] / М. Гогулян. - М.: Советский спорт, 2002. $-302 \mathrm{c}$.

5. Росс, Х. Селекция картофеля. Проблемы и перспективы [Текст] / Х. Росс. - М.: Агропромиздат, 1989. - 184 с.

6. Энгельс, Ф. Диалектика природы [Текст] / Ф. Энгельс - М.: Политиздат, 1969. - С. 154.

7. Skiebe, K. Die genetischen Ursachen von Hybrideffekten [Text] / K. Skeibe // BioL Zentialb. 1977. - № 96. - P. 303 - 319.

8. Подгаецкий, А. А. Межвидовая несовместимость картофеля. Методы и способы ее преодоления: метод. рекомен. [Текст] / А. А. Подгаецкий. - К.: УААН, ИКХ, 1993. - 99 с.

9. Подгаецкий, А. А. Некоторые особенности вовлечения в гибридизацию вида S. bulbocastanum Dun. [Текст] / А. А. Подгаецкий // Тезисы докладов IY съезда генетиков и селекционеров Украины. - К.: Наукова думка, 1981. - Ч. 4. - С. 51-53.

10. Подгаецкий, А. А. Межвидовая гибридизация в селекции картофеля в Украине [Текст] / А. А. Подгаецкий // Вавиловский журнал генетики и селекции. - 2012. - Т. 16. - № 2. C. $471-479$.

11. Подгаецкий, А. А. Использование генофонда картофеля в селекции на фитофтороустойчивость: методические рекомендации [Текст] / А. А. Подгаецкий. - К.: УААН, УНИИКХ, 1991. - 48 с.

12. Подгаєцький, А. А. Цистоутворюючі нематоди картоплі та боротьба з ними (Стан, аналіз та рекомендації) [Текст] / А. А. Подгаєцький, Т. Г. Мірошник. - К., 1995. - 79 с.

13. Жолуденко, О. В. Створення скоростиглого селекційного матеріалу картоплі [Текст]: автореф. дис. ... канд. с.-г. наук: 06.01.05 / О. В. Жолуденко: [Інститут рослинництва ім. В. Я. Юр'єва НААН]. - Х., 2005. - 19 с.

14. Методичні рекомендації щодо проведення досліджень з картоплею [Текст]. Немішаєве, 2002. $-189 \mathrm{c}$.

\section{References}

1. FAO Statistical Yeabook, 2014. Europe and Central Asia Food and Agriculture. Food and Agriculture Organization of the Unitid Nations. Regional Offise for Europe and Centrel Asia. Budapest, 2014. $130 \mathrm{p}$.

2. Van der Zaag DE. Potato production and utilization in the world. Pot Res. 1976; 19:7-22.

3. Vlasenko MYu. Morphology, physiology and biochemistry of potato. Potato. T 1. Kyiv; 2002. P. 54-115.

4. Gogulian M. Say "Good bye" to diseases. Moscow: Sovetskiy sport. 2002. 302 p.

5. Ross H. Potato breeding. Problems and prospects. Moscow: Agropromizdat. 1989. 184 p.

6. Engels F. Dialectics of Nature. Moscow: Politizdat. 1969. P. 154.

7. Skiebe K. Die genetischen Ursachen von Hybrideffekten. BioL Zentialb. 1977; 96:303-319.

8. Podgaietskiy AA. Interspecies incompatibility of potato. Methods and ways to overcome it. Kyiv: UAAS, IPP. 1993. 99 p.

9. Podgaietskiy AA. Some peculiarities of involvement the species S. bulbocastanum Dun. in hybridization. In: Proceeding of the IY Congress of Geneticists and Breeders of Ukraine. Kyiv: Naukova dumka; 1981. P. 51-53.

10. Podgaietskiy AA. Interspecific hybridization in potato breeding in Ukraine. Vavilov Journal of genetics and breeding. 2012; 16(2):471-479. 
11. Podgaietskiy AA. Use of potato gene pool in breeding for resistance to Irish potato famine fungus: Guidelines. Kyiv: UAAS, Ukrainian Scientific-Research Institute of Potato Farming; 1991. 48 p.

12. Podgaietskiy AA, Miroshnik TG. Potato cyst-forming nematodes and methods of their control (Status, analysis and recommendations). Kyiv; 1995. 79 p.

13. Zholudenko OV. Creation of early-season potato breeding material: [dissertation]. [Plant Production Institute nd. a V. Ya. Yuriev of NAAS, (Kharkiv)]: Kharkiv; 2005.

14. Guidelines for research with potato. Nemishaievo; 2002. 189 p.

\section{ПЕРСПЕКТИВНОСТЬ РАЗЛИЧНЫХ ПО СПЕЛОСТИ МЕЖВИДОВЫХ ГИБРИДОВ КАРТОФЕЛЯ ПО СОДЕРЖАНИЮ КРАХМАЛА И ЕГО ВЫХОДА}

Подгаецкий А. А., Крючко Л. В.

Сумской национальный аграрный университет, Украина

Цель и задачи исследования. Целью исследований было определение селекционной ценности различных по группе спелости межвидовых гибридов картофеля, созданных с участием мексиканских диких видов, по содержанию крахмала в клубнях и его выхода в пересчете на растение. Определение влияния метеорологических условий на проявление названных признаков.

Материалы и методы. Методика исследований - общепринятая в картофелеводстве, в частности оценка исходного предселекционного и исходного селекционного материала. Исходным материалом были межвидовые гибриды, полученные при участии трех-, четырех-, пяти- и шести диких и культурных видов. Общим для всех их было присутствие в родословной вида $S$. bulbocastanum. Они создавались методами беккроссирования, caмоопыления на разных этапах и скрещивания гибридов между собой.

Обсуждение результатов. Доказан значительный потенциал гибридов, их беккроссов по содержанию крахмала. Даже в очень неблагоприятном для формирования крахмала 2012 году значительная часть исследованного материала превышала значение сортовстандартов. Еще больше такого материала было в лучших для формирования крахмала 2013 г. и особенно в 2014 г. Доля гибридов с уровнем признака больше 22,0 \% среди очень позднеспелых гибридов составляла 20,0 \% и 25,0 \%.

Низкое содержание крахмала у раннеспелых гибридов в 2012 году обусловило также низкий его выход в перерасчете на растение. Все такие гибриды отнесены к классу со значением 40,0 г/растение и меньше. В следующем году они были представлены в двух классах, а в 2014 - в трех, до 120 г/растение. Выделены многочисленные межвидовые гибриды, их беккроссы, которые значительно превышали значение показателя у сортовстандартов, что в благоприятных условиях составляло больше 200 г/растение. Они также характеризовались селекционной ценностью по другим признакам.

Выводы. Выделенные межвидовые гибриды, их беккроссы, характеризующиеся высоким фенотипическим проявлением отдельных или нескольких признаков, следует широко использовать в селекционной практике как родительские формы. Для более эффективного применения целесообразно определить их комбинационную способность по контролю агрономических признаков.

Ключевые слова: картофель, межвидовой гибрид, беккросс, содержание крахмала, выход крахмала, метеорологические условия 


\section{PROSPECTS FOR INTERSPECIFIC POTATO HYBRIDS OF VARIOUS RIPENESS IN \\ TERMS OF STARCH CONTENT AND YIELD}

Podgaietskiy A.A., Kriuchko L.V.

Sumy National agrarian university, Ukraine

The article presents the research results on breeding value of interspecific potato hybrids, which belong to various ripeness groups and were generated with involvement of Mexican wild species, in terms starch content in tubers and starch yield per plant.

The aim and tasks of the study was to evaluate the potential of interspecific hybrids of various ripeness and their backcrosses by starch content, starch yield per plant and the effect of meteorological conditions during the experiment years on trait expression.

Materials and methods. Source material was interspecific hybrids obtained with involvement of three, four, five and six wild and cultivated species. Presence in the origin of S. bulbocastanum species was common to all combinations. They were created by backcrossing, self-pollination at different stages and hybrid crossing between one another.

Results and Discussion. A substantial potential of hybrids and their backcrosses in terms of starch content was proved. Even in 2012, which was very unfavorable for starch formation, a significant portion of the investigated material exceeded values of standard varieties. In 2013 and especially in 2014, which were better for starch formation, there was much more of such material. The proportion of hybrids with the trait level of greater than $22.0 \%$ was $20.0 \%$ and $25.0 \%$ among very late-ripening hybrids, respectively.

Low starch content in early-ripening hybrids in 2012 determined its low yield per plant. All such hybrids were referred to the class of $40.0 \mathrm{~g} / \mathrm{plant}$ value and lower. In the next year, they were presented in two classes, and in 2014 - in three classes, up to $120 \mathrm{~g} /$ plant.

Conclusions. Numerous interspecific hybrids and their backcrosses greatly exceeding the standard varieties by this parameter, which under favorable conditions was greater than $200 \mathrm{~g} / \mathrm{plant}$, were identified. They were also noticeable for breeding value by other traits.

Key words: potato, interspecific hybrids, backcross, starch content, starch yield, meteorological conditions

УДК 633.11,,321”:631.523

\section{ТРАНСГРЕСИВНА МІНЛИВІСТЬ ОЗНАК ПРОДУКТИВНОСТІ ГІБРИДІВ ДРУГОГО ПОКОЛІННЯ ПШЕНИЦ ТВЕРДОЇ ЯРӦ̈}

Хоменко С. О., Федоренко М. В.

Миронівський інститут пшениці імені В. М. Ремесла НААН, Україна

Наведено результати дослідження характеру успадкування ознак продуктивності рослин (довжина колоса, кількість колосків у колосі, кількість зерен з колоса та маса зерна 3 колоса) у другому поколінні гібридів пшениці твердої ярої. Встановлені різні показники коефіцієнта успадковуваності в залежності від ознаки та комбінації схрещування.

Ключові слова: пшениця тверда яра, трансгресія, продуктивність, гібрид

Вступ. Трансгресивна мінливість відноситься до факторів появи у процесі розщеплення гібридів таких гомозиготних за полімерними генами генотипів, які за спектром мінли-

(C) С. О. Хоменко, М. В. Федоренко. 2015.

ISSN 0582-5075. Селекція і насінництво. 2015. Випуск 107. 